\title{
P02.177. Effects of Bach Rescue remedy on cardiac autonomic balance in healthy women
}

\author{
S Yang, Y Wang* \\ From International Research Congress on Integrative Medicine and Health 2012 \\ Portland, Oregon, USA. 15-18 May 2012
}

\section{Purpose}

The Rescue remedy has been used as a stress relief formula by practitioners of Bach flower remedies. The objective of the present study is to evaluate the effect of Bach Rescue remedy on cardiac autonomic balance in healthy women.

\section{Methods}

In this two-stage crossover trial, seven females (mean age $26 \pm 4$ years) were randomlyassigned to a sequence of two treatments (Rescue remedy and placebo) with a onemonth wash-out period. The Rescue remedy consisted of four drops of five flower essences (cherry plum, clematis, impatiens, rock rose and Star of Bethlehem) dissolved in brandy and $250 \mathrm{ml}$ of distilled water. The placebo consisted of four drops of brandy in $250 \mathrm{ml}$ of distilled water. Cardiac autonomic functions were evaluated by frequency domain indices (LF, low frequency power and HF, high frequency power) of heart rate variability at baseline and after the intervention. Percentage changes were calculated and compared between the Rescue remedy and placebo groups using Wilcoxon signed rank sum test.

\section{Results}

Both the mean percentage changes of LnLF (natural logarithm-transformed LF) and LF/HF ratio were significantly different between the two groups. The mean percentage change of LnLF in the Rescue remedy group was $-15.9+/-7.4 \%$ compared with $18.3+/-21.6 \%$ in the placebo group. The mean percentage change of $\mathrm{LF} / \mathrm{HF}$ was $-27.8+/-13.0 \%$ in the Rescue remedy group compared with $53.2+/-89.1 \%$ in the placebo group.

\section{Institute of Natural Healing Sciences, NanHua University, DaLin, ChiaYi,} Taiwan

\section{() Biomed Central}

(c) 2012 Yang and Wang; licensee BioMed Central Ltd. This is an Open Access article distributed under the terms of the Creative Commons Attribution License (http://creativecommons.org/licenses/by/2.0), which permits unrestricted use, distribution, and reproduction in any medium, provided the original work is properly cited.

\section{Conclusion}

This is the first study using a double-blind randomized crossover design to evaluate the effect of Bach Rescue remedy on heart rate variability in healthy women. Increased parasympathetic activity and decreased sympathetic activity were observed in individuals receiving Bach Rescue remedy. These changes may explain the stress relieving effect of Bach Rescue remedy.

Published: 12 June 2012

doi:10.1186/1472-6882-12-S1-P233

Cite this article as: Yang and Wang: P02.177. Effects of Bach Rescue

remedy on cardiac autonomic balance in healthy women. $B M C$

Complementary and Alternative Medicine 2012 12(Suppl 1):P233.
Submit your next manuscript to BioMed Central and take full advantage of:

- Convenient online submission

- Thorough peer review

- No space constraints or color figure charges

- Immediate publication on acceptance

- Inclusion in PubMed, CAS, Scopus and Google Scholar

- Research which is freely available for redistribution 